\title{
Developmental potential of cloned mouse embryos reconstructed by a conventional technique of nuclear injection
}

\author{
A. Rybouchkin, B. Heindryckx, J. Van der Elst and M. Dhont \\ Department of Obstetrics and Gynaecology, Poli 3, Ghent University Hospital, \\ De Pintelaan 185, B-9000, Ghent, Belgium
}

The fact that most of the advances in mouse cloning by nuclear transfer originate from research in a limited number of laboratories demonstrates the complexity of the reported technologies. The development of alternative and more simple techniques of nuclear transfer may therefore be of interest. Furthermore, the preimplantation biology of cloned mouse embryos originating from somatic cells has not yet been studied in detail. In the present study, a modified conventional injection $(\mathrm{mCl})$ technique for cloning mice from somatic cells is described. The preimplantation development and morphology of the resulting nuclear transfer embryos in comparison with parthenogenetic embryos and embryos obtained by intracytoplasmic sperm injection (ICSI) under comparable conditions was also studied. Finally, the capacity of nuclear transfer embryos for full-term development was investigated. Eighty-nine per cent of oocytes injected with cumulus cell nuclei under $\mathrm{mCl}$ conditions survived and formed zygotes. However, the rate of development of these zygotes to the blastocyst stage was significantly lower $(29 \%)$ than that of ICSI or parthenogenetic zygotes (95 and $92 \%$, respectively). Cloned blastocysts had a significantly lower mean number of cells in the inner cell mass (9) and trophectoderm (52) and a lower inner cell mass:total cell ratio $(14 \%)$ than did their counterparts $(31,143$ and $18 \%$ for ICSI and 21, 92 and $18 \%$ for parthenogenetic blastocysts, respectively). This correlated with a significantly higher proportion of dead cells in the cloned blastocysts. The poor quality of cloned blastocysts may explain the low rate of full-term fetal development of somatic mouse clones.

\section{Introduction}

Several protocols have been developed recently for somatic cell cloning of laboratory mice, particularly with respect to the technique for transfer of the nucleus into the oocyte cytoplasm. Most results were obtained using a piezo-driven nuclear injection protocol, which was initially developed by Kimura and Yanagimachi (1995) for ICSI and later applied to cloning by Wakayama et al. (1998). However, workers in many laboratories have failed to produce cloned mice using this method (Ogura et al., 2000a). Successful authors report a high survival rate after injection of enucleated oocytes with cumulus cell nuclei $(75-95 \%)$, a high rate of pseudo-pronucleus formation among surviving oocytes $(90-100 \%)$ and a high rate of development of zygotes to the morula or blastocyst stage (40-70\%) (Wakayama et al., 1998, 1999, 2000; Kishikawa et al., 1999; Wakayama and Yanagimachi, 1999, 2001a,b). In contrast, the results of other authors using the same piezomethod are much more modest. Munsie et al. (2000) reported that after piezo-actuated injection of cumulus nuclei only $39 \%$ of the oocytes survived and only $4 \%$ of cleaved nuclear transfer embryos reached the blastocyst stage. Zhou et al. (2000) reported an even lower survival

Email: andrei.rybouchkin@rug.ac.be rate $(6 \%)$ using the same experimental approach and no embryos developed to the blastocyst stage. Therefore, further elaboration, understanding and meticulous description of all steps of this method are necessary before it can be applied widely.

A conventional technique of injection might provide an alternative method for somatic nuclear transfer in mice. Aspiration of cytoplasm into the injection needle (membrane stretching) is used instead of a piezo-pulse to penetrate the oocyte membrane. This procedure has been successfully applied for ICSI of human and mouse oocytes (Van Steirteghem et al., 1993; Rybouchkin et al., 1995; Dozortsev et al., 1996) and yielded cloned animals after somatic nuclear transfer (Zhou et al., 2000). However, the rates of survival (46\%), activation (64\%) and blastocyst development $(8 \%)$ reported by Zhou et al. (2000) were relatively low compared with the data reported for the piezo-technique (both groups have used cumulus cells as nuclear donors). Hence, there is ample room for improvement of this conventional injection technique.

It appears that reduction of the temperature during injection and the addition of fetal bovine serum (FBS) might increase the rate of survival of mouse oocytes after the conventional method of nuclear injection, as demonstrated for ICSI in mice by Kimura and Yanagimachi (1995) and Suzuki and Yanagimachi (1997). Indeed, these conditions may double the rate of oocyte survival after nuclear 
injection by a conventional technique (Rybouchkin and Dhont, 2000). However, the effect of temperature on oocyte survival was contradicted by Zhou et al. (2000), although these authors did not report any data to substantiate their statement. Whether reduction of the temperature or the addition of FBS is useful for improving the rate of oocyte survival needs further confirmation.

Of even greater importance than the rates of oocyte survival and zygote formation is the developmental potential of embryos obtained by nuclear transfer. Unfortunately, the results in the literature in this respect are not presented uniformly. In some reports, morula and blastocyst stages have been indiscriminately put together as a single endpoint for estimating the developmental capacity of embryos obtained by nuclear transfer (Wakayama et al., 1998, 1999, 2000; Wakayama and Yanagimachi, 2001a,b), although development of a significant number of nuclear transfer embryos is arrested at the morula stage (Heindryckx et al., 2001). Moreover, even blastocysts may represent a highly heterogeneous group of embryos with a widely varying developmental potential, as even embryos with as few as four cells may form a blastocoelic cavity (Surani et al., 1980; Dean and Rossant, 1984). Therefore, it is surprising that no detailed description of blastocyst quality after somatic cell nuclear transfer in mice has been reported to date. The data reported for other species are also scarce and limited to the analysis of only a few blastocysts (Koo et al., 2000).

The aims of the present study were: (i) to investigate whether cooling during injection or the addition of FBS to the medium used for oocyte incubation during injection or both might have a beneficial effect on the survival of the oocytes after nuclear injection; (ii) to analyse the quality of the blastocysts obtained by the conventional technique of nuclear transfer; and (iii) to evaluate the conventional nuclear transfer technique with respect to full-term fetal development of the embryos obtained.

\section{Materials and Methods}

\section{Experimental design}

In a first series of six replicated experiments, cumulus cell nuclei were injected into mouse oocytes; during injection the oocytes were incubated at room $\left(25-28^{\circ} \mathrm{C}\right)$ or reduced $\left(16-18^{\circ} \mathrm{C}\right)$ temperatures and in the presence or absence of $20 \%$ FBS. The effects of these conditions on rates of survival and pseudo-pronucleus formation in injected oocytes and early cleavage divisions of resulting embryos were analysed up to the morula stage. The use of FBS and reduced temperature at the time of conventional nuclear transfer is referred to subsequently as 'modified conventional injection' ( $\mathrm{mCl}$ ).

In a second series of six replicated experiments, preimplantation development up to the blastocyst stage and blastocyst quality of the nuclear transfer embryos obtained by the $\mathrm{mCl}$ technique were compared with that of ICSI embryos also obtained by the $\mathrm{mCl}$ technique and also with diploid parthenogenetic embryos.

In a third series of eight replicated experiments, the capacity of nuclear transfer embryos produced by the $\mathrm{mCl}$ technique to full-term fetal development was analysed by transferring them to pseudopregnant recipients.

\section{Animals}

Mice were purchased from IFFA Credo (Brussels) and were handled according to the guidelines of the Animal Research Ethical Committee of the Ghent University Hospital. The mice were kept under controlled temperature $\left(23 \pm 2{ }^{\circ} \mathrm{C}\right)$ and lighting conditions, and food and water were available ad libitum. B6D2 F1 (C57Bl/6J $\times$ DBA/2) hybrid female mice aged 7-12 weeks were used as a source of oocytes and cumulus nuclear donor cells. The mice were kept under an inverted light:dark cycle regimen with $14 \mathrm{~h}$ light (from 13:00 $\mathrm{h}$ to $03: 00 \mathrm{~h}$ ) and $10 \mathrm{~h}$ dark to obtain freshly ovulated oocytes on the morning of the day of experiment. Females were superovulated by subcutaneous injection of 8-10 iu eCG at about 21:00 h, with an i.p. injection of 8-10 iu hCG about 48 h later.

\section{Media, reagents and equipment}

The components for preparation of media and solutions were purchased from Sigma (Sigma-Aldrich nv/sa, Bornem) unless stated otherwise. BSA was purchased from Calbiochem (no. 12657; Euro Biochem, Scrl., Bierges). Equine and human chorionic gonadotrophins (eCG, Folligon and hCG, Chorulon) were obtained from Intervet (Mechelen). Polyvinylpyrrolidone (PVP) solution and G2 medium were purchased from IVF Science Scandinavia (Hunter Sciences, Widdington). FBS was obtained from GibcoBRL (no. 10120152; Life Technologies, Merelbeke).

Oocyte handling, injection, activation and culture media were prepared on the basis of FHM and KSOM media (Lawitts and Biggers, 1993). All media contained $4 \mathrm{mg}$ BSA ml-1 instead of the $1 \mathrm{mg} \mathrm{ml}^{-1}$ reported for original FHM and KSOM media.

All microinstruments were prepared using a Narishige's puller PB-7 and microforge MF-9 (Omnilabo, Aartselaar) with estimation of the needle diameters under an inverted microscope at $\times 400$ magnification. The micromanipulation set up consisted of hydraulic Narishige's micromanipulators MO-202, microinjectors IM-6 and an Olympus IX70 inverted microscope with Hoffman modulation contrast (Omnilabo).

\section{Oocyte recovery, partial zona dissection and enucleation}

At 13.0-13.5 $\mathrm{h}$ after hCG administration the females were killed and cumulus-oocyte complexes (COCs) were transferred to $50 \mu \mathrm{l}$ droplets of FHM with 200 iu hyaluronidase (type VIII) $\mathrm{ml}^{-1}$ for 5 min to disperse cumulus cells. Oocytes were washed free from hyaluronidase by brief 
rinsing in several droplets of FHM and either transferred to 3-5 $\mu$ l droplets of FHM under mineral oil in a manipulation chamber (cover of a $60 \mathrm{~mm}$ Petri dish (no. 3002; Becton Dickinson Benelux nv, Aalst)) or kept in a $\mathrm{CO}_{2}$ incubator in $50 \mu \mathrm{l}$ droplets of KSOM under mineral oil before use.

Partial zona dissection and enucleation were performed at $37^{\circ} \mathrm{C}$. Before enucleation, the zona pellucida of all experimental oocytes was dissected on 10-15\% of their circumference with a fine glass needle directly above the spindle area. It took about $30 \mathrm{~min}$ to make a slit in the zona pellucida of each of 60 oocytes. For enucleation, groups of 15-20 oocytes were placed in a micromanipulation chamber in FHM supplemented with $1 \mu \mathrm{g}$ cytochalasin $\mathrm{D} \mathrm{ml} \mathrm{m}^{-1}$. A blunt polished pipette with inside diameter of $10-15 \mu \mathrm{m}$ was inserted through the slit in the zona pellucida. Metaphase plates were easily identifiable in B6D2 oocytes as transparent, not granulated, areas that appeared more solid than the rest of the cytoplasm. Metaphase plates were aspirated into the enucleation pipette with the smallest amount of surrounding cytoplasm possible. If doubts occurred in the correct identification of the metaphase plate or its secure enucleation, the oocyte was discarded. Pilot experiments on enucleation and staining of enucleated oocytes by Hoechst H33342 had shown the $100 \%$ effectivity of this method. After enucleation, the oocytes were washed free from cytochalasin D and kept in the incubator in KSOM medium for up to $4 \mathrm{~h}$ before being used for nuclear injection. It took about 70-80 min to enucleate 60 oocytes.

\section{Preparation of nuclear donor cells and spermatozoa}

Cumulus cells obtained during oocyte recovery were washed twice in FHM by short (15 s) centrifugation at $500 \boldsymbol{g}$ and were transferred to a central $1 \mu \mathrm{l}$ droplet of FHM under mineral oil in a manipulation chamber for storage for 2-4 $\mathrm{h}$ at room temperature. At $0.5-1.0 \mathrm{~h}$ before nuclear injection, about $3 \mu$ of freshly thawed $10 \%$ (w/v) PVP solution was added to the droplet with the cells to facilitate their handling during nuclear transfer.

Spermatozoa were recovered from the cauda epididymides of 4-12-month-old CD-1 males in FHM medium and were prepared for injection in the same way as described for cumulus cells.

\section{Nuclear transfer}

Pilot experiments showed that oocytes are most sensitive to damage by the injection procedure during the first $30 \mathrm{~min}$ after enucleation. Therefore, the groups of oocytes were used for nuclear transfer in their order of enucleation, but not earlier than $1 \mathrm{~h}$ after enucleation. In the first series of experiments, the groups of enucleated oocytes were allocated intermittently for nuclear injection to FHM medium with or without $20 \%$ FBS and at either room $\left(25-28^{\circ} \mathrm{C}\right)$ or reduced $\left(16-18^{\circ} \mathrm{C}\right)$ temperature. In the second and third series of experiments, all nuclear transfers or ICSI were performed under $\mathrm{mCl}$ conditions.
When oocytes had to be injected in the presence of $20 \%$ FBS, they were rinsed in a separate $50 \mu \mathrm{l}$ droplet of FHM with serum before transfer to $2-3 \mu$ d droplets of the same medium in the manipulation chamber. An additional droplet of FHM was used to remove excess PVP surrounding the injection needle, when it was travelling between the droplet with oocytes and the droplet with cumulus cells-PVP. All manipulations were performed on an inverted microscope stage under the control of a microscope thermal stage controller, MTS-1 (Techne, Duxford), to control temperature during injection. Equilibration of the temperature between manipulation chamber and microscope stage was allowed for 15 min before injections were started.

Injection pipettes with an inside diameter of $6-7 \mu \mathrm{m}$ were prepared immediately before use. The pipettes were filled with a highly viscous inert fluid, dimethylpolysiloxane (DMPS-12M), and were attached through Teflon tubing to the microinjector to ensure smooth movement of the nuclei inside the pipette during injection.

The presence of PVP in the droplet with cumulus cells caused the cells to spread and attach to the surface of the manipulation chamber. The injection pipette was used to touch and press one of the processes of the spread out cells far aside from the nucleus. Damage to the cellular membrane led to shrinkage of the cell nucleus in the hypertonic PVP solution. Hence, the nucleus could be easily drawn inside the injection pipette without excessive mechanical deformation, thereby reducing the possibility of the damage to chromosomes (Rybouchkin et al., 2000). Typically, two to four nuclei were aspirated in the injection pipette in this way (separated from each other by a distance of about $100 \mu \mathrm{m})$. The injection pipette was moved to the droplet containing oocytes incubated in injection medium. The injection pipette was inserted deep into the oocyte through the slit in the zona pellucida, creating an invaginated pocket. The donor nucleus was brought to the very tip of the injection pipette and the oocyte cytoplasm was slowly aspirated until breakage of the cellular membrane was clearly visible. The nucleus was then injected into the oocyte cytoplasm with the smallest amount of medium possible. It took approximately 25-30 min to inject a group of 20 enucleated oocytes. After all oocytes in a group were injected they were incubated for $15 \mathrm{~min}$ at the temperature of injection $\left(17-18^{\circ} \mathrm{C}\right.$ or $\left.25-28^{\circ} \mathrm{C}\right)$. If injections were performed at a reduced temperature $\left(17-18^{\circ} \mathrm{C}\right)$ the oocytes were incubated for an additional $15 \mathrm{~min}$ at room temperature. The injected oocytes were transferred to culture medium (KSOM) for $1-3 \mathrm{~h}$ incubation at $37.2^{\circ} \mathrm{C}$ in an atmosphere of $6 \% \mathrm{CO}_{2}$ in air before activation.

\section{Intracytoplasmic sperm injection}

In the second series of experiments, random groups of sibling oocytes were not enucleated and were either activated parthenogenetically (not injected control; NIC) or were subjected to ICSI. Motile spermatozoa were selected for injection. Sperm heads were separated from the tails by 
pressing spermatozoa with the injection needle to the bottom of the manipulation chamber at the neck region and concomitant head-ward movement of the needle. Separated heads were injected into zona pellucida-dissected oocytes in the same mechanical way as the nuclei of cumulus cells. The inside diameter of the injection needle was about $7 \mu \mathrm{m}$.

\section{Oocyte activation and embryo culture}

At 1-3 $\mathrm{h}$ after nuclear injection, the oocytes were activated by incubation in calcium-free KSOM supplemented with $10 \mathrm{mmol} \mathrm{SrCl}_{2} \mathrm{I}^{-1}$ and $2 \mu \mathrm{g}$ cytochalasin $\mathrm{D} \mathrm{ml} \mathrm{m}^{-1}$ for $6 \mathrm{~h}$. At the end of activation treatment the oocytes were evaluated on the basis of formation of pseudo-pronuclei, washed through three droplets of plain KSOM and cultured further for $56-60 \mathrm{~h}$ in $\mathrm{KSOM}$ at $37.2^{\circ} \mathrm{C}$ in an atmosphere of $6 \%$ $\mathrm{CO}_{2}$. From $60 \mathrm{~h}$ to $72-76 \mathrm{~h}$ or $120 \mathrm{~h}$ the oocytes were cultured in G2 medium under the same conditions. Nonenucleated oocytes were activated and cultured in the same way to serve as controls for activation procedure and quality of culture media. The oocytes injected with spermatozoa were not subjected to the activation procedure, but they were cultured in the same way. The development of nuclear transfer, parthenogenetic and ICSI-derived embryos was recorded at $24 \mathrm{~h}$ intervals from the start of activation treatment.

\section{Blastocyst analysis}

Blastocysts obtained from nuclear transfer, after parthenogenetic activation and after fertilization by ICSI were analysed at $120 \mathrm{~h}$ after the start of activation treatment by a differential staining technique originally described by Hardy et al. (1989). In brief, zonae pellucidae were removed by a short treatment of blastocysts in acid Tyrode solution and blastocysts were incubated for $10 \mathrm{~min}$ in $0.5 \%$ (v/v) picrylsulphonic acid in PBS at $4^{\circ} \mathrm{C}$. After washing in FHM, the blastocysts were incubated for $10 \mathrm{~min}$ in $30 \%$ rabbit anti-DNP-BSA antiserum in FHM at $37^{\circ} \mathrm{C}$. After brief washing in $\mathrm{FHM}$, the blastocysts were further treated for $10 \mathrm{~min}$ in $20 \%$ guinea-pig serum complement in $\mathrm{FHM}$ supplemented with $20 \mu \mathrm{g}$ propidium iodide $\mathrm{ml}^{-1}$ at $37^{\circ} \mathrm{C}$. Finally, the blastocysts were washed in BSA-free FHM supplemented with $10 \mu \mathrm{g}$ propidium iodide $\mathrm{ml}^{-1}$ and fixed in ice-cold ethanol for $10 \mathrm{~min}$. The blastocysts were stained overnight using $10 \mu \mathrm{g}$ Hoechst $33528 \mathrm{ml}^{-1}$ in absolute ethanol at $4{ }^{\circ} \mathrm{C}$. For observation and nuclear counting, the blastocysts were transferred to $2 \mathrm{ml}$ glycerol in a watch glass and were then transferred separately to $0.5 \mu$ l droplets of glycerol on a glass slide. When covered and spread out with a coverslip the blastocysts were observed at $\times 400$ and $\times 1000$ magnification under an Axioplan 2 fluorescent microscope (Carl Zeiss nv-sa, Zaventem) with filter set 02, allowing concomitant observation of red (propidium iodide) stained trophectoderm nuclei and green-blue (Hoechst) stained inner cell mass (ICM) nuclei. Blastocyst nuclei were counted on the monitor attached to the microscope through a CCD video camera. Each nucleus
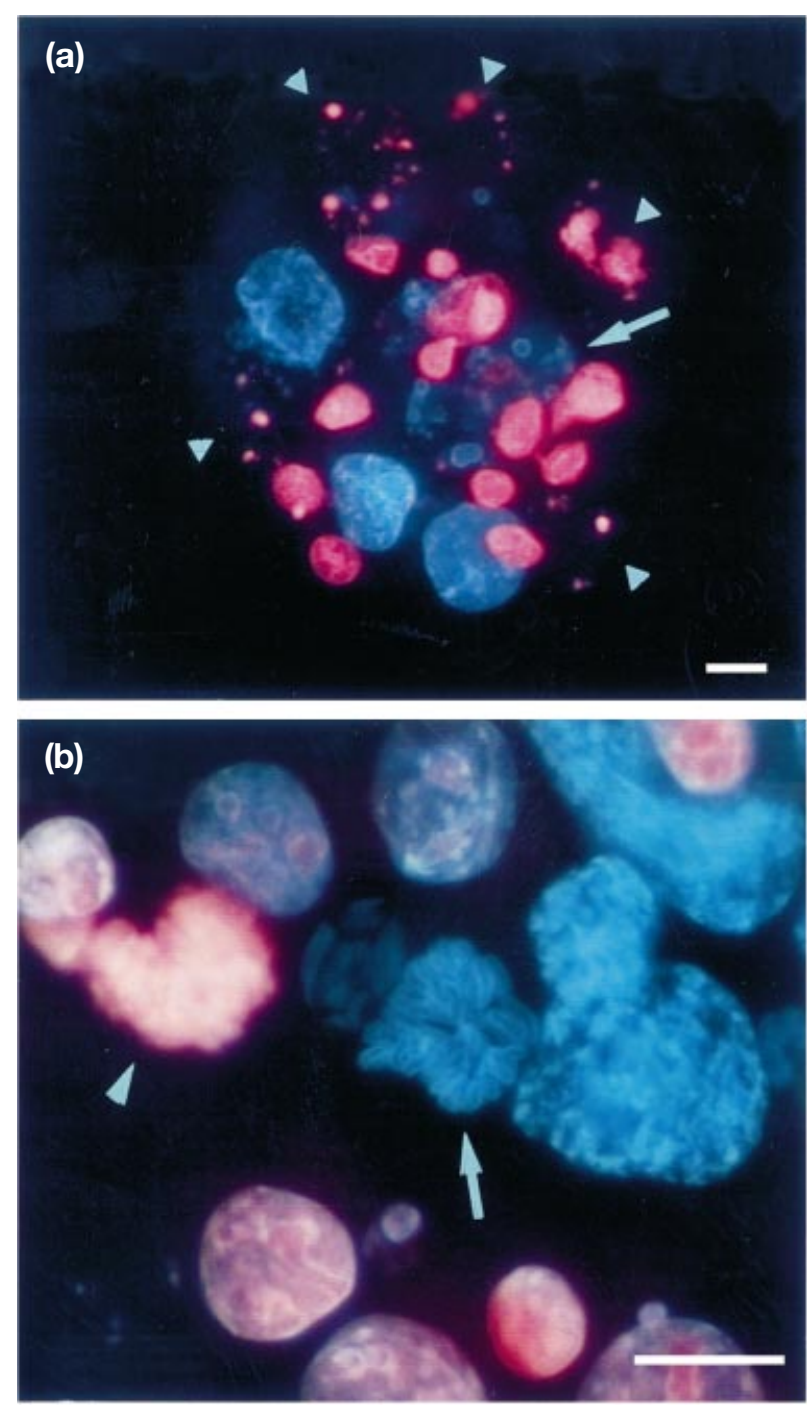

Fig. 1. Identification of dead and mitotic cells in mouse blastocysts. (a) A cloned mouse blastocyst with numerous apoptotic, nuclear fragmented cells in trophectoderm (triangles) and inner cell mass (ICM; arrow) cells. (b) Mitotic figures among trophectoderm (arrowhead) and ICM (arrow) cells. Scale bars represent $10 \mu \mathrm{m}$.

was labelled on the monitor screen by a marker to prevent repeated counting. Dead cells were identified as having a pycnotic, shrunken nucleus or as undergoing nuclear fragmentation (Fig. 1a). Mitotic cell index and dead cell index were calculated as ratio of the number of mitotic or dead cells to the total cell number multiplied by $100 \%$.

\section{Embryo transfer}

Pseudopregnant CD-1 females mated with proven sterile CD-1 males were used as embryo recipients. Nuclear transfer embryos at the two- or four-cell stage were transferred to the oviducts of females on day 0.5 after mating, and embryos at the morula/blastocyst stage were 
Table 1. Effect of temperature reduction and presence of serum during nuclear injection on the rates of survival, pseudo-pronucleus formation and early preimplantation development of nuclear transfer mouse embryos

\begin{tabular}{|c|c|c|c|c|c|c|c|}
\hline \multirow{2}{*}{$\begin{array}{l}\text { Temperature } \\
\text { during injection } \\
\left({ }^{\circ} \mathrm{C}\right)\end{array}$} & \multirow{2}{*}{$\begin{array}{l}\text { Presence } \\
\text { of serum }\end{array}$} & \multirow{2}{*}{$\begin{array}{l}\text { Number of } \\
\text { oocytes } \\
\text { injected }\end{array}$} & \multirow{2}{*}{$\begin{array}{c}\text { Number of } \\
\text { oocytes that } \\
\text { survived (\%)* }\end{array}$} & \multirow{2}{*}{$\begin{array}{l}\text { Number with } \\
\text { psuedo- } \\
\text { pronucleus } \\
(\%)^{*}\end{array}$} & \multicolumn{3}{|c|}{$\begin{array}{c}\text { Number of oocytes with } \\
\text { pseudo-pronucleus reaching each stage }\end{array}$} \\
\hline & & & & & Two-cell (\%)** & Four-cell or more $(\%)^{+}$ & Morula $(\%)^{* *}$ \\
\hline \multirow[t]{2}{*}{$25-28$} & - & 278 & $150(54)^{\mathrm{cg}}$ & $146(53)$ & $137(94)$ & $83(30)^{f}(57)$ & $64(44)$ \\
\hline & + & 165 & $104(63)^{\mathrm{b}}$ & $102(62)$ & $96(94)$ & $55(33)^{\mathrm{e}}(54)$ & $49(45)$ \\
\hline \multirow[t]{2}{*}{$16-18$} & - & 123 & $80(65)^{\mathrm{ag}}$ & 79 (64) & $72(92)$ & $46(37)^{d}(58)$ & $37(47)$ \\
\hline & + & 269 & $245(91)^{\mathrm{abc}}$ & $240(89)$ & $226(94)$ & 131 (49) def (55) & $114(48)$ \\
\hline
\end{tabular}

*Percentage per number of oocytes injected; ${ }^{* *}$ percentage per number of oocytes with pseudo-pronucleus; ${ }^{\dagger}$ percentage per number of oocytes injected and percentage per number of oocytes with pseudo-pronucleus, respectively.

a-gPercentages marked with the same superscripts are significantly different $\left({ }^{a-c}, \mathrm{e}-\mathrm{f} P<0.001\right.$ and $\left.{ }^{\mathrm{d} g} P<0.04\right)$, Fisher's exact test.

transferred to the uterine horns of recipient females on days 2.5-3.5 after mating. Before transfer, recipient mice were anaesthetized by i.p. injection of $100 \mu \mathrm{l}$ sodium pentobarbital (Nembutal; Sanofi, Brussels) that had been diluted 1:4 in PBS. Caesarian section and uterine analysis for implantation sites were performed on all recipients between day 18.5 and day 20.5 after mating. If available, lactating foster mothers were used to raise live pups.

\section{Statistical analysis}

Contingency tables of the rates of survival, activation, preimplantation development and implantation were analysed by two-sided Fisher's exact test. Differences in total number of cells and the numbers of ICM and trophectoderm cells, dead and mitotic cell indices in blastocysts were analysed for significance using a one-way ANOVA test, or the Kruskal-Wallis (non-parametric ANOVA) test, when data did not fit a Gaussian distribution.

\section{Results}

\section{Effect of cooling and presence of serum on survival, pseudo-pronucleus formation and cleavage}

The results of experiments on the influence of different temperatures and the presence of serum during injection on rates of oocyte reconstruction and cleavage are shown (Table 1). The addition of $20 \%$ serum to the oocyte incubation medium during injection at room temperature did not improve the rate of oocyte survival. In addition, reduction of the temperature without serum supplementation led to only minimal improvement in oocyte survival. The combination of serum supplementation with reduction of the temperature during injection led to a highly significant increase in rate of oocyte survival compared with all other conditions.

Most (97-99\%) of the oocytes that survived injection formed one to three (mainly two) pseudo-pronuclei, irrespective of the method of injection and most of those with pseudo-pronuclei had cleaved to the two-cell stage at $24 \mathrm{~h}$ after the start of activation treatment. Other phenotypes observed were immediate cleavage, one-cell arrest and fragmentation, but these occurred only rarely. Immediate cleavage means that immediately after recovery from the medium with strontium and cytochalasin $(6 \mathrm{~h}$ after the start of activation treatment), an oocyte had cleaved to two cells and had four cells at the time of evaluation $(24 \mathrm{~h}$ after the start of activation treatment). These embryos, as well as fragmented and arrested embryos, were separated from the rest of the normal two-cell embryos and were excluded from further analysis.

No significant differences were found among different injection groups as to the capacity of activated oocytes (oocytes with pseudo-pronuclei) to reach the four-cell stage or more at $48 \mathrm{~h}$ after the start of activation treatment. However, if calculated per number of oocytes injected, the $\mathrm{mCl}$ protocol yielded a significantly higher number of fourcell embryos. No further culture of nuclear transfer embryos beyond the morula stage was performed in this series of experiments.

\section{Preimplantation development and blastocyst quality of nuclear transfer, ICSI and parthenogenetic embryos}

Data on preimplantation development of nuclear transfer and ICSI embryos both obtained with $\mathrm{mCl}$ conditions, as well as on development of parthenogenetic embryos, are shown (Table 2). Irrespective of their origin, most of the cultured zygotes were able to cleave to two cells during the first $24 \mathrm{~h}$ after the start of activation treatment. At this stage, the rare abnormalities among parthenogenetic embryos were mainly due to immediate cleavage, whereas a few nuclear transfer embryos showed either one-cell arrest or fragmentation. The most significant loss among nuclear transfer embryos was observed at the transition from the two- to the four-cell stage. At $48 \mathrm{~h}$ after the start of activation treatment, roughly half of the nuclear transfer embryos cleaved to four or more (up to eight) blastomeres, whereas the remainder was arrested at the two- or three-cell stage. In a few nuclear transfer embryos, one of the two blastomeres cleaved more than once, whereas the second blastomere remained arrested. Despite having four or more 
Table 2. Preimplantation development of nuclear transfer, control and parthenogenetic mouse embryos from the one-cell stage

\begin{tabular}{|c|c|c|c|c|c|c|}
\hline \multirow[b]{2}{*}{ Group } & \multirow{2}{*}{$\begin{array}{c}\text { Number } \\
\text { of embryos } \\
\text { cultured }\end{array}$} & \multicolumn{5}{|c|}{ Developmental stages reached by embryos at different times after start of activation treatment $(\%)^{*}$} \\
\hline & & $\begin{array}{c}24 \mathrm{~h} \\
\text { (two-cell) }\end{array}$ & $\begin{array}{l}48 \mathrm{~h} \text { (four-cell } \\
\text { or more) }\end{array}$ & $\begin{array}{c}72-74 \text { h (morula } \\
\text { or blastocyst) }\end{array}$ & $\begin{array}{c}96 \mathrm{~h} \\
\text { (blastocyst) }\end{array}$ & $\begin{array}{c}120 \mathrm{~h} \\
\text { (blastocyst) }\end{array}$ \\
\hline Nuclear transfer & 367 & $339(92)$ & $169(46)^{\mathrm{ab}}$ & $137(37)^{\mathrm{cd}}$ & $69(19)^{\text {ef }}$ & $107(29)$ gh \\
\hline ICSI & 38 & $38(100)$ & $37(97)^{\mathrm{a}}$ & $37(97)^{\mathrm{c}}$ & $36(95)^{\mathrm{e}}$ & $36(95)^{\mathrm{g}}$ \\
\hline Uninjected control & 92 & $87(95)$ & $87(95)^{b}$ & $86(93)^{d}$ & $80(87)^{f}$ & $85(92)^{\mathrm{h}}$ \\
\hline
\end{tabular}

ICSI: intracytoplasmic sperm injection; *percentage per number of one-cell stage embryos cultured.

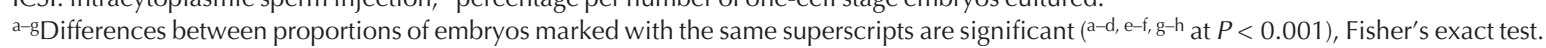

Table 3. Blastocyst quality of nuclear transfer and control mouse embryos

\begin{tabular}{|c|c|c|c|c|c|c|c|c|}
\hline \multirow[b]{2}{*}{ Group } & \multirow{2}{*}{$\begin{array}{c}\text { Number of } \\
\text { blastocysts } \\
\text { analysed }\end{array}$} & \multirow{2}{*}{$\begin{array}{c}\text { Number of } \\
\text { TE cells } \\
\text { (mean } \pm \mathrm{SD})^{*}\end{array}$} & \multirow{2}{*}{$\begin{array}{c}\text { Number of } \\
\text { ICM cells } \\
\text { (mean } \pm \mathrm{SD})^{*}\end{array}$} & \multirow{2}{*}{$\begin{array}{c}\text { ICM/total } \\
\text { cell number } \\
\text { (mean } \pm \mathrm{SD} \text { ) }\end{array}$} & \multicolumn{2}{|c|}{$\begin{array}{c}\text { TE quality } \\
(\text { mean } \pm \text { SEM, } \%)\end{array}$} & \multicolumn{2}{|c|}{$\begin{array}{c}\text { ICM quality } \\
(\text { mean } \pm \text { SEM, } \% \text { ) }\end{array}$} \\
\hline & & & & & $\begin{array}{l}\text { Mitotic } \\
\text { index }\end{array}$ & $\begin{array}{l}\text { Dead cell } \\
\text { index }\end{array}$ & $\begin{array}{c}\text { Mitotic } \\
\text { index }\end{array}$ & $\begin{array}{l}\text { Dead cell } \\
\text { index }\end{array}$ \\
\hline Nuclear transfer & 82 & $51.6 \pm 29.9$ & $8.6 \pm 7.2$ & $0.14 \pm 0.09^{a b}$ & $0.9 \pm 0.3$ & $7.0 \pm 2.0^{\mathrm{cd}}$ & $3 \pm 1$ & $21 \pm 5^{\text {ef }}$ \\
\hline ICSI & 20 & $143.3 \pm 32.5$ & $31.2 \pm 7.6$ & $0.18 \pm 0.05^{\mathrm{a}}$ & $0.8 \pm 0.1$ & $0.3 \pm 0.1^{c}$ & $2 \pm 1$ & $2 \pm 1^{\mathrm{e}}$ \\
\hline Uninjected control & 73 & $91.9 \pm 24.4$ & $21.0 \pm 9.0$ & $0.18 \pm 0.07^{b}$ & $0.7 \pm 0.3$ & $0.3 \pm 0.1^{d}$ & $3 \pm 1$ & $4 \pm 1^{f}$ \\
\hline
\end{tabular}

TE: trophectoderm; ICM: inner cell mass; ICSI: intracytoplasmic sperm injection.

*Differences between all means are significant $(P<0.001)$ by one-way ANOVA; ${ }^{\text {ab }}$ difference between means labelled with the same superscript is significant by one-way ANOVA $\left({ }^{\mathrm{a}} P<0.05\right.$ and $\left.{ }^{\mathrm{b}} P<0.01\right)$; ${ }^{\mathrm{c}-\mathrm{f}}$ difference between means labelled with the same superscript is significant by Kruskal-Wallis test (non-parametric ANOVA); ${ }^{\mathrm{c}}$ and ${ }^{\mathrm{d}} P<0.001$, ${ }^{\mathrm{e}} P<0.01$ and ${ }^{\mathrm{f}} P<0.05$.

cells these embryos with unequal blastomeres were not considered as having reached the four-cell stage; most of these embryos did not develop to the blastocyst-like stage. At least $80 \%$ of the nuclear transfer embryos reaching the four-cell stage or more at $48 \mathrm{~h}$ after the start of activation treatment were able to cleave further and were at the compacted morula stage at $72-74 \mathrm{~h}$ after the start of activation treatment. However, it should be noted that at this developmental stage an identification bias could already exist, as some of the embryos were not fully compacted or had too few cells and, thus, scoring them as having reached the morula stage was equivocal.

Only a few nuclear transfer embryos had started cavitation at $72-74 \mathrm{~h}$ after the start of activation treatment in our experimental conditions. This is in contrast to embryos obtained by parthenogenetic activation and by ICSI; on average, $40-60 \%$ of these embryos had reached the early blastocyst stage at this time. A considerable number of nuclear transfer morulae $36 \%$ of those finally reaching blastocyst stage at $120 \mathrm{~h}$ after the start of activation treatment) had not started cavitation even at $96 \mathrm{~h}$ after the start of activation treatment, whereas only a few control parthenogenetic and ICSI embryos $(<3-6 \%)$ showed a delay of cavitation at this time. The differences between nuclear transfer zygotes and ICSI or parthenogenetic zygotes in the capacity to reach the advanced (beyond twocell stage) preimplantation development stages (four-cell, morula, blastocyst) were highly significant.
The quality of nuclear transfer, ICSI and parthenogenetic blastocysts was evaluated further by analysis of the number of cells of the ICM and the trophectoderm, and the proportion of dead cells and cells undergoing mitosis (Table 3, Figs 1 and 2). There were significant differences among all three groups of blastocysts in the number of cells in the trophectoderm and the ICM. Nuclear transfer blastocysts had the lowest number of cells, whereas blastocysts originating from ICSI had the most. The mean proportion of ICM cells to the total number of cells in the parthenogenetic and ICSI blastocysts was not different, whereas in nuclear transfer blastocysts it was significantly reduced. The proportion of dead cells in the trophectoderm and ICM was significantly higher for nuclear transfer blastocysts than for parthenogenetic or ICSI blastocysts. Mitotic cell indices for all three groups were equal.

\section{Full-term development of cloned embryos obtained by $\mathrm{mCl}$ technique}

The results of experiments on estimation of the potential of nuclear transfer embryos to undergo full-term fetal development are shown (Table 4). Observation of implantation sites (Fig. 3a) showed that significantly more embryos implanted after transfer to the uterus at the morula or blastocyst stage compared with after transfer to the oviduct at the two- to four-cell stage. Transfer of 314 nuclear transfer embryos yielded three live pups $(0.5 \%$ of injected 
Table 4. Full-term development of nuclear transfer mouse embryos obtained by a modified conventional injection technique

\begin{tabular}{|c|c|c|c|c|c|c|c|}
\hline \multirow{2}{*}{$\begin{array}{l}\text { Embryo } \\
\text { stage at } \\
\text { transfer }\end{array}$} & \multirow{2}{*}{$\begin{array}{l}\text { Recipient stage } \\
\text { (days after } \\
\text { mating) }\end{array}$} & \multirow{2}{*}{$\begin{array}{l}\text { Number of } \\
\text { embryos } \\
\text { transferred }\end{array}$} & \multirow{2}{*}{$\begin{array}{l}\text { Number of } \\
\text { pregnancies/ } \\
\text { recipient* }\end{array}$} & \multirow{2}{*}{$\begin{array}{l}\text { Total number of } \\
\text { implantation } \\
\text { sites }(\%)\end{array}$} & \multicolumn{2}{|c|}{ Number of pups at term } & \multirow{2}{*}{$\begin{array}{c}\text { Number of } \\
\text { adults }\end{array}$} \\
\hline & & & & & Dead & Alive & \\
\hline Two- to four-cell & 0.5 & 156 & $6 / 9$ & $29(19 \%)^{a}$ & $0(0)$ & $1(0.6)$ & $1(0.6)$ \\
\hline Morula or blastocyst & $2.5-3.5$ & 158 & $8 / 10$ & $63(40 \%)^{b}$ & $1(0.6)^{* *}$ & $2(1.3)$ & $0(0)$ \\
\hline
\end{tabular}

Values in parentheses are percentages of embryo transferred.

*Animals with any uterine signs of implantation at days $18-20$ after mating; **about day 16.5 of development.

abPercentages with different superscripts within the same column are significantly different $(P<0.001)$.
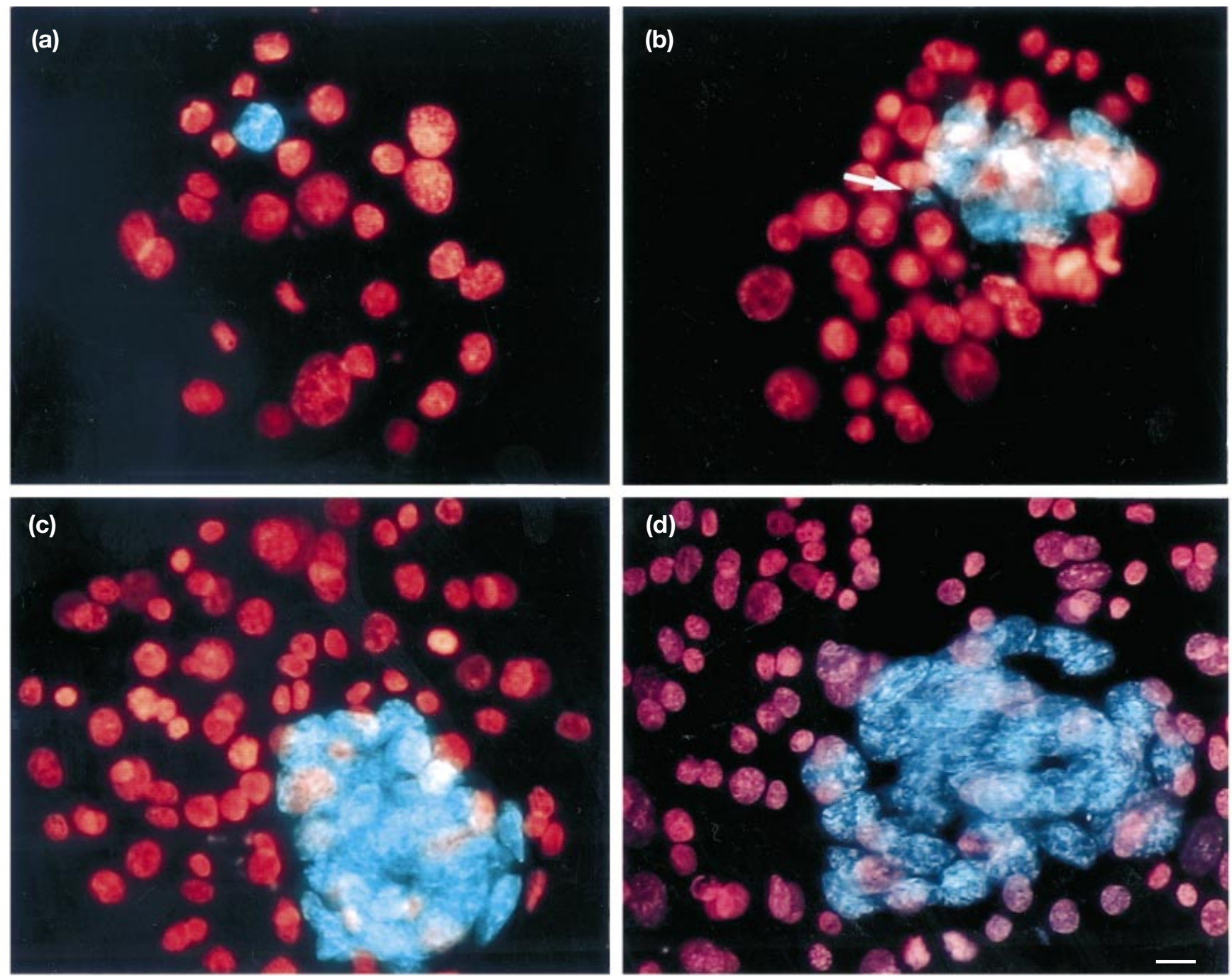

Fig. 2. Composition of mouse blastocyst developed in vitro from (a,b) cloned zygotes, (c) a parthenogenetic diploid zygote and (d) an intracytoplasmic sperm injection (ICSI)-derived zygote. Note (a) the single inner cell mass (ICM) cell in one cloned blastocyst and (b) fragmented nucleus (arrow) in the relatively well developed ICM of another cloned blastocyst. Scale bar represents $10 \mu \mathrm{m}$.

oocytes or $1 \%$ of transferred embryos). Two of the pups were obtained by transfer of morula or blastocyst embryos into the uterine horns. The fetuses and corresponding placentae weighed $2.288 \mathrm{~g}$ and $0.528 \mathrm{~g}$, and $1.708 \mathrm{~g}$ and $0.318 \mathrm{~g}$, respectively. The first pup lived for 1 day and died, probably due to outfeeding by the older ( 5 days difference) foster siblings (no closer-matching lactating mother was available). For the second cloned pup, no matching feeding mother was available and Caesarian section was performed on the anaesthetized female. The pup died within 15 min 

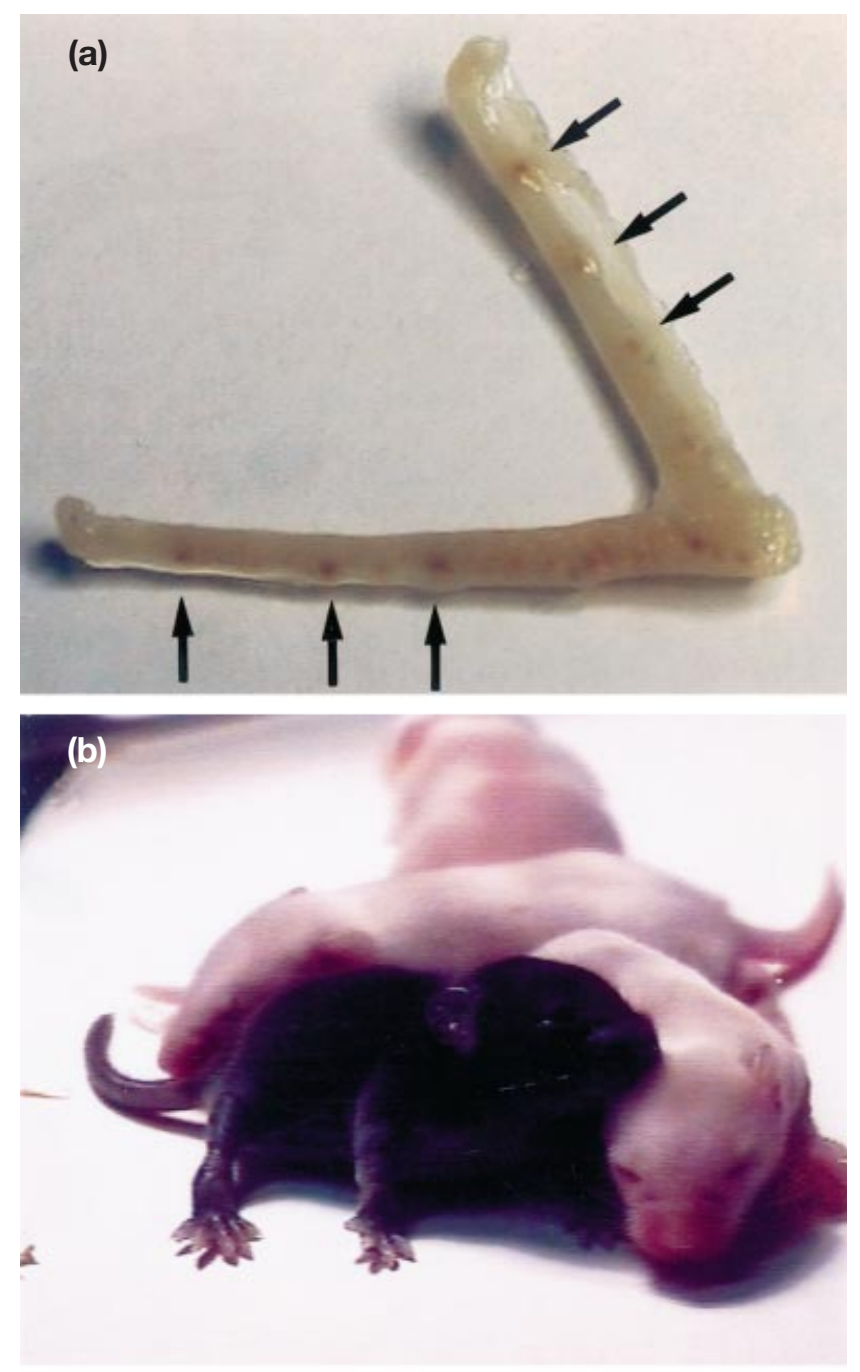

Fig. 3. Post-implantation development of mouse clones. (a) Implantation sites (arrows) observed in a pseudopregnant female at day 19 after mating, after transfer of cloned embryos. (b) Live surviving cloned animal of black fur colour, corresponding to B6D2 F1 nuclear donor cell origin delivered by pseudopregnant CD-1 $\times$ CD-1 albino female and fed among CD-1 albino foster siblings.

after recovery, possibly due to increased sensitivity to anaesthesia.

The single surviving cloned pup was obtained after transfer of a two-cell embryo into the oviduct. Its weight was $1.496 \mathrm{~g}$ and its placenta weighed $0.364 \mathrm{~g}$. It was raised by a lactating foster mother together with a limited number (three) of foster siblings delivered on the same day as the cloned pup (Fig. 3b).

The 'clone' status of the pups obtained was supported unequivocally by their coat and eye colours (both black) characteristic to nuclear donor strain (B6D2 F1) in contrast to red eyes and white coat colour of CD-1 recipient females and proven sterile, vasectomized albino CD-1 males used to generate pseudopregnancy.

\section{Discussion}

The biological mechanisms underlying successful cloning remain poorly understood (Pennisi and Vogel, 2000). According to the literature, the most successful method for nuclear transfer in mice is the piezo-driven technique (Wakayama et al., 1998; Ogura et al., 2000b; Zhou et al., 2001) but this method should not yet be considered as the ultimate in nuclear transfer technology. As well as the rather expensive equipment needed (Suzuki and Yanagimachi, 1997), some workers have been unable to reproduce the same success rate as initially reported (Munsie et al., 2000; Pennisi and Vogel, 2000; Zhou et al., 2000). Failure to adhere to the strict rules of the reported technology or the omission of some important details in the description of the technology could explain the lack of reproducibility.

A conventional (without piezo-drive unit) nuclear transfer technique was recently applied for somatic nuclear transfer in mice and yielded live cloned animals (Zhou et al., 2000). However, the rates of survival, pseudopronucleus and blastocyst formation were relatively low. Better results were obtained by cooling of oocytes at the time of injection and by addition of FBS (Rybouchkin and Dhont, 2000; Heindryckx et al., 2001). Although the beneficial effect of cooling was contradicted by Zhou et al. (2000), no numerical data to prove this statement were provided. Therefore, the aim of the present study was to reconfirm our previous data on the effect of oocyte cooling and the addition of serum. According to our new set of data, the addition of serum to the oocyte-incubation-duringinjection medium and reduction of the temperature during injection (to $16-18^{\circ} \mathrm{C}$ ) are both important for a high survival rate after the conventional method of injection. Our results also show that oocyte cooling per se, without addition of serum, has only a minimal effect on oocyte survival, which may explain the negative results on the effect of cooling reported by the above-mentioned authors.

The first and perhaps the major stumbling block in the development of cloned embryos obtained in our experiments was the second cleavage division. On average, up to $50 \%$ of the embryos failed to complete this stage. The same problem was reported by some other groups (Kato et al., 1999; Zhou et al., 2000) for cloned embryos created without application of serum or oocyte cooling during nuclear transfer. Unfortunately, in many reports the various stages of preimplantation development are not mentioned separately (Wakayama et al., 1998; Wakayama and Yanagimachi, 2001a,b) or the evaluation of embryonic development is limited to the blastocyst stage (Kishikava et al., 1999; Munsie et al., 2000; Amano et al., 2001a,b; Eggan et al., 2001). The reason for the high rate of two- to threecell arrest of nuclear transfer embryos observed in our and other experiments is as yet speculative. The transition of maternal to embryonic control is a critical period during which environmental factors may play a crucial role. This situation is not unlike the so-called 'two-cell block' that is observed during culture of the embryos of some strains of 
mice. In both cases, proper selection of culture medium facilitates the development of embryos beyond the two-cell stage (Gardner and Lane, 1996; Heindryckx et al., 2001). However, the high rate of arrest at the three-cell stage and the occurrence of binucleate blastomeres (Heindryckx et al., 2001) point to a significant difference between nuclear transfer embryos and embryos of 'two-cell blocking' strains. In this respect, it is interesting to note that knockout mutants of the anti-apoptotic gene Ced-9 in Caenorrhabditis elegans (homologous to mammalian $\mathrm{BCl}-2$ ) also show arrest at early stages of embryo development combined with asynchronous, delayed cleavage and presence of multinucleated blastomeres, resulting from abnormal cytokinesis (Hengartner et al., 1992). This may correlate further with the high rate of cell death and lower number of cells in nuclear transfer blastocysts found in our experiments. Whether abnormalities in the expression of $\mathrm{BCl}-2$ or its counterparts, the caspase family genes, are involved in the developmental arrest of nuclear transfer embryos remains to be investigated.

The four-cell stage $(48 \mathrm{~h}$ after the start of activation treatment) is the last stage of preimplantation development of cloned embryos that can be analysed without significant bias. Indeed, at $62 \mathrm{~h}$ (time of transfer to G2 medium) and later (72 $\mathrm{h}$ after the start of activation treatment), the embryos are already partially or fully compacted and the level of compaction or the number of cells in compacted morulae cannot be estimated accurately.

The start of cavitation is the next landmark for evaluation of preimplantation embryos (Van Soom et al., 1997). In our experiments, only very few nuclear transfer embryos had started cavitation at $76 \mathrm{~h}$ after the start of activation treatment, whereas approximately $50 \%$ of the control embryos had started cavitation at this time. Kishikawa et al. (1999) also reported a significant, but lower, rate of cavitation for nuclear transfer $(30 \%)$ versus control parthenogenetic $(60 \%)$ morulae at this time. In our experiments, about $50 \%$ of nuclear transfer morula stage embryos reached the blastocyst stage at $96 \mathrm{~h}$ after the start of activation treatment, whereas almost all control morulae did so at this time. Considering these facts, it may be speculated that delayed cavitation is a characteristic feature of cloned embryos.

Co-ordinated expression of multiple gene families is necessary for successful cavitation (Warner and Brenner, 2001; Watson and Barcroft, 2001) and delay of cavitation in nuclear transfer embryos may point to a disturbance in the expression patterns of these genes. No data on gene expression for cloned mouse embryos are yet available, but cloned bovine embryos appear to be prone to aberrant gene expression (Lavoir et al., 1997; Daniels et al., 2000). However, the fact that most $(80 \%)$ of the cloned morulae had reached the blastocyst stage in our experiments at $120 \mathrm{~h}$ after the start of activation treatment might indicate that reprogramming of the genome of cumulus cells has still taken place and that aberrant expression of genes during cavitation might be transient or not completely blocking.
Although many of the cloned morulae finally reached the blastocyst stage, the quality of these blastocysts was inferior to that of blastocysts from parthenogenetic or ICSI origin, as indicated by the lower total number of cells and the lower ICM:total cell ratio. A reduced number of cells in nuclear transfer blastocysts compared with blastocysts obtained by IVF in pigs was recently reported by Koo et al. (2000), demonstrating that this phenomenon is not species-specific.

It has been demonstrated previously that the number of cells in the blastocysts and their relative composition (ICM:trophectoderm) depends on the number of cells in morulae at the onset of cavitation (Tarkowski and Wroblewska, 1967; Ansell and Snow, 1975; Rossant, 1976). However, there is growing evidence that blastocyst composition, if not number of cells, may be regulated by programmed cell death (apoptosis) (Brison and Schultz, 1997; Hardy, 1997). Our data show that nuclear transfer blastocysts have a significantly higher proportion of dead cells in trophectoderm and in the ICM than do parthenogenetic or ICSI blastocysts at $120 \mathrm{~h}$ after the start of activation treatment. Whether the higher rate of cell death in cloned blastocysts is related to the low number of cells in corresponding morulae or originates independently during the blastocyst stage is not yet clear.

In total, about $40 \%$ of two-cell stage in vitro-cultured nuclear transfer embryos had reached the morula or blastocyst stage in the present study. This may also be the case after transfer of two-cell embryos into the oviduct and may explain why the implantation rate per number of twocell transferred embryos is about twice as low as that for morula/blastocyst stage transfers.

A correlation between the number of cells in the blastocyst and in the ICM and fetal development has been demonstrated previously (Rossant, 1976; Tam, 1988; Lane and Gardner, 1997). This may conform with our own results. Cloned blastocysts had the lowest number of cells in the ICM and trophectoderm, and few embryos were able to complete full-term fetal development after transfer in vivo. This demonstrates that analysis of the quality of cloned blastocysts may be a valuable predictor of the full-term development of cloned embryos.

In conclusion, the experiments reported here show that a modified conventional injection technique yields a high reconstruction rate and, therefore, can be applied for nuclear transfer cloning experiments in mice. With this technique, a considerable number of cloned embryos were obtained that developed to blastocysts, some of which may develop to full term. Both nuclear transfer and control ICSI embryos obtained by this technique develop equally well to the two-cell stage. However, further development of nuclear transfer embryos is much less effective than in controls (arrest at two- to three-cell stage, delayed cavitation, low total number of cells and high rate of dead cells in the blastocysts). Considering that from the two-cell stage onward development largely depends on the correct pattern of expression of the embryonic genome, the incomplete reprogramming of the somatic nucleus may be 
speculated to be a main underlying reason. Whether this is an intrinsic feature of cloned embryos or is linked to some procedural aspects of this particular nuclear transfer technique should be investigated.

This study was partially supported by a research grant by BijZOF 01110301 of the Ghent University, Belgium. Authors are grateful to Jun Liu for help in learning blastocyst staining and embryo transfer techniques, Liesbeth Dansschotter, graduate student of Ghent College of Industrial Science for excellent technical assistance and Vera David for help in everyday animal care.

\section{References}

Amano T, Tani T, Kato Y and Tsunoda Y (2001a) Mouse cloned from embryonic stem (ES) cells synchronized in metaphase with nocodazole Journal of Experimental Zoology 289 139-145

Amano T, Kato Y and Tsunoda Y (2001b) Full-term development of enucleated mouse oocytes fused with embryonic stem cells from different cell lines Reproduction 121 729-733

Ansell JD and Snow MHL (1975) The development of trophoblast in vitro from blastocysts containing varying amounts of inner cell mass Journal of Embryology and Experimental Morphology 33 175-185

Brison DR and Schultz RM (1997) Apoptosis during mouse blastocyst formation: evidence for a role for survival factors including TGF- $\alpha$ Biology of Reproduction 56 1088-1096

Daniels R, Hall V and Trounson AO (2000) Analysis of gene transcription in bovine nuclear transfer embryos reconstructed with granulosa cell nuclei Biology of Reproduction 63 1034-1040

Dean WL and Rossant J (1984) Effect of delaying DNA replication on blastocyst formation in the mouse Differentiation 26 134-137

Dozortsev D, De Sutter P, Rybouchkin A and Dhont M (1996) Methodology of intracytoplasmic sperm injection in the human Assisted Reproduction Review 6 38-44

Eggan K, Hidenori A, Loring J, Jackson-Grusby L, Klemm M, Rideout WM, Yanagimachi R and Jaenisch R (2001) Hybrid vigor, fetal overgrowth, and viability of mice derived by nuclear cloning and tetraploid embryo complementation Proceedings National Academy of Sciences USA 98 6209-6214

Gardner DK and Lane M (1996) Alleviation of the '2-cell block' and development to the blastocyst stage of CF1 mouse embryos: role of amino acids, EDTA and physical parameters Human Reproduction 11 2703-2712

Hardy K (1997) Cell death in the mammalian blastocyst Molecular Human Reproduction 3 919-925

Hardy K, Handyside AH and Winston RML (1989) The human blastocyst: cell number, death and allocation during late preimplantation development in vitro. Development 107 597-604

Heindryckx B, Rybouchkin A, Van der Elst J and Dhont M (2001) Effect of culture media on in vitro development of cloned mouse embryos Cloning 3 41-50

Hengartner MO, Ellis RE and Horvitz HR (1992) C. elegans gene ced-9 protects from programmed cell death Nature 356 494-499

Kato Y, Yabuuchi A, Motosugi N, Kato J and Tsunoda Y (1999) Developmental potential of mouse follicular epithelial cells and cumulus cells after nuclear transfer Biology of Reproduction $\mathbf{6 1}$ 1110-1114

Kimura Y and Yanagimachi R (1995) Intracytoplasmic sperm injection in the mouse Biology of Reproduction 52 709-720

Kishikawa H, Wakayama T and Yanagimachi R (1999) Comparison of oocyte-activating agents for mouse cloning Cloning 1 153-159

Koo DB, Kang YK, Choi YH et al. (2000) In vitro development of reconstructed porcine oocytes after somatic cell nuclear transfer Biology of Reproduction 63 986-992

Lane M and Gardner DK (1997) Differential regulation of mouse embryo development and viability by amino acids Journal of Reproduction and Fertility 109 153-164
Lavoir MC, Kelk D, Rumph N, Barnes F, Betteridge KJ and King WA (1997) Transcription and translation in bovine nuclear transfer embryos Biology of Reproduction $\mathbf{5 7}$ 204-213

Lawitts JA and Biggers JD (1993) Culture of preimplantation embryos. In Methods in Enzymology, Guide to Techniques in Mouse Development 225 pp 153-165 Eds PM Wassarman and ML DePamphilis. Academic Press, New York

Munsie MJ, Michalska AE, O'Brien CM, Trounson AO, Pera MF and Mountford PS (2000) Isolation of pluripotent embryonic stem cells from reprogrammed adult mouse somatic cell nuclei Current Biology 10 989-992

Ogura A, Inoue K, Takano K, Wakayama T and Yanagimachi R (2000a) Birth of mice after nuclear transfer by electrofusion using tail tip cells Molecular Reproduction and Development 57 55-59

Ogura A, Inoue K, Ogonuki N et al. (2000b) Production of male cloned mice from fresh, cultured, and cryopreserved immature sertoli cells Biology of Reproduction 62 1579-1584

Pennisi E and Vogel G (2000) Clones: a hard act to follow Science 288 1722-1727

Rossant J (1976) Postimplantation development of blastomeres isolated from 4- and 8-cell mouse eggs Journal of Embryology and Experimental Morphology 36 283-290

Rybouchkin A and Dhont M (2000) Nuclear transfer into mouse oocytes by a conventional method of injection Theriogenology 53241 (Abstract)

Rybouchkin A, Dozortsev D, De Sutter P, Qian C and Dhont M (1995) Intracytoplasmic injection of human sperm into mouse oocytes: a useful model to investigate oocyte activating capacity and the karyotype of human sperm Human Reproduction 10 1130-1135

Rybouchkin A, Heindryckx B, Van der Elst J and Dhont M (2000) Mechanical and chemical damage of chromosomes during intracytoplasmic nuclear injection Human Reproduction 15 Abstract Book 173 Abstract 0-182

Surani MA, Barton SC and Burling A (1980) Differentiation of 2-cell and 8-cell mouse embryos arrested by cytoskeletal inhibitors Experimental Cell Research 125 275-286

Suzuki K and Yanagimachi R (1997) Beneficial effect of medium with high concentration serum for direct sperm injection into mouse oocytes using a conventional pipette Zygote 5 111-116

Tam PP (1988) Postimplantation development of mitomycin C-treated mouse blastocysts Teratology 37 205-212

Tarkowski AK and Wroblewska J (1967) Development of blastomeres of mouse eggs isolated at the 4- and 8-cell stage Journal of Embryology and Experimental Morphology 18 155-180

Van Soom A, Ysebaert MT and De Kruif A (1997) Relationship between timing of development, morula morphology, and cell allocation to inner cell mass and trophectoderm in in vitro-produced bovine embryos Molecular Reproduction and Development 47 47-56

Van Steirteghem AC, Nagy P, Joris H, Liu J, Staessen C, Smitz J, Wisanto A and Devroey $\mathbf{P}$ (1993) High fertilization and implantation rates after intracytoplasmic sperm injection Human Reproduction 8 1061-1066

Wakayama T and Yanagimachi R (1999) Cloning of male mice from adult tail-tip cells Nature Genetics 22 127-128

Wakayama T and Yanagimachi R (2001a) Mouse cloning with nucleus donor cells of different age and type Molecular Reproduction and Development 58 376-383

Wakayama T and Yanagimachi R (2001b) Effect of cytokinesis inhibitors, DMSO and the timing of oocyte activation on mouse cloning using cumulus cell nuclei Reproduction 122 49-60

Wakayama T, Perry ACF, Zuccotti M, Johnson KR and Yanagimachi R (1998) Full-term development of mice from enucleated oocytes injected with cumulus cell nuclei Nature 394 369-374

Wakayama T, Rodriguez I, Perry ACF, Yanagimachi R and Mombaerts P (1999) Mice cloned from embryonic stem cells Proceedings National Academy of Sciences USA $9614984-14989$

Wakayama T, Tateno H, Mombaerts P and Yanagimachi R (2000) Nuclear transfer into mouse zygotes Nature Genetics 24 108-109

Warner CM and Brenner CA (2001) Genetic regulation of preimplantation embryo survival Current Topics in Developmental Biology 52 151-192 
Watson AJ and Barcroft LC (2001) Regulation of blastocyst formation Frontiers in Bioscience 6 708-730

Yabuuchi A, Tani T, Kato Y and Tsunoda Y (2001) Nuclear transfer of mouse follicular epithelial cells pretreated with spermine, protamine, or putrescine Journal of Experimental Zoology 289 208-212

Zhou Q, Boulanger L and Renadr JP (2000) A simplified method for the reconstruction of fully competent mouse zygotes from adult somatic donor nuclei Cloning 2 35-44

Zhou Q, Jouneau A, Brochard V, Adenot P and Renard JP (2001)
Developmental potential of mouse embryos reconstructed from metaphase embryonic stem cell nuclei Biology of Reproduction 65 412-419

Received 11 February 2002.

First decision 18 March 2002.

Revised manuscript received 22 April 2002.

Accepted 16 May 2002. 